London, on May 25, when Sir George will deliver an address, entitled "Fifty Years' Work in Geomagnetism and Geophysics: Some Reminiscences". Sir George's work covers a wide range, the most important aspects being atmospheric electricity and thunderstorms, terrestrial radiation, climatic changes in geological times, geophysical observations on Captain Scott's last Antarctic Expedition and their discussion, and water vapour and condensation in the atmosphere. Early in his career, Sir George went to Lapland to study atmospherics in high latitudes; but his main work began with his theory of the origin of the electricity of thunderstorms. His most important work was probably that with Scrase and Robinson in the design of a very simple instrument, many of which were sent up by means of balloons into thunderclouds to give a definite indication of the potential gradient and its magnitude. In this way he obtained the first clear picture of the positions of the charges in a thundercloud and their sign. He accompanied Scott on his last expedition to the Antarctic and was in charge of the work on meteorology, atmospheric electricity and terrestrial magnetism. One of the important results of this was a collection of data on the semi-diurnal oscillation of atmospheric pressure and on water vapour condensation in the atmosphere for these high altitudes.

\section{Physical Society: Annual General Meeting}

THe annual general meeting of the Physical Society will be held on May 2 at 4.30 p.m. in the Lecture Theatre of the Royal Institution, and will be followed at 5 p.m. by an address by Prof. Sydney Chapman, Sedleian professor of natural philosophy in the University of Oxford. Prof. Chapman was president of the Society for the year 1949-50, but was unable to continue his second year of office owing to a longterm engagement in the United States. His subject for this deferred presidential address will be "Some Phenomena of the Upper Atmosphere". Prof. Chapman is mainly known for work on three aspects of research on the earth's atmosphere. In the late 1920's he worked largely on the turbulent transfer of heat in the lower atmosphere. He then turned his attention to the constitution of the upper atmosphere and considered in particular the balance of atomic oxygen, molecular oxygen and ozone in the atmosphere, and the relation of this balance to auroras. This latest work has been in connexion with the determination of the lunar atmospheric tides at a number of stations distributed over the whole world.

\section{New B.B.C. Transmitter}

A MARKED technical advance in the distribution of the 'Third Programme' of the B.B.C. materialized on April 8, when a new high-power transmitter was brought into operation at Daventry. Since the Copenhagen plan of wave-lengths for European broadcasting stations came into operation in March 1950, the Third Programme has been radiated on two wave-lengths, $464 \mathrm{~m}$. $(647 \mathrm{kc} . / \mathrm{s}$. $)$ and $194 \mathrm{~m}$. $(1,546 \mathrm{kc} . / \mathrm{s}$.$) , using twenty-three transmitters to give$ a service to about fifty per cent of the population. With the new transmitter installed at Daventry, the power radiated from this station on the 464-m. wavelength has been increased almost three-fold to $150 \mathrm{~kW}$., the maximum permitted under the Copenhagen plan. The new installation consists of two identical selfcontained transmitters, each giving an output of $100 \mathrm{~kW}$. They are normally operated in parallel at reduced power; but should a fault occur on one, it can be switched off and the other brought up to full power for the short time necessary to locate and correct the fault. This is a more economical method of maintaining a virtually uninterrupted programme than that of using two separate transmitters -one in operation and one spare-each capable of the full power output needed. Another feature of the new station is that it is provided with a single mastradiator, $725 \mathrm{ft}$. high, erected on a site $460 \mathrm{ft}$. above sea-level, at a distance of a mile and a quarter from the transmitter building. The feeder from the transmitter is connected to this aerial at such a height as will concentrate the maximum radiation along the ground. The combined features of high power and more efficient aerial are expected to result in good non-fading reception over an area of a radius of at least a hundred miles. This area is bounded by a circle approximately through Manchester, Grimsby, Ipswich, Chatham, Southampton and Cardiff; and with the supplementary transmissions already in operation, it should bring the number of listeners able to receive the programme up to about seventy per cent of the population.

\section{Leaf Scald Disease of Sugar Cane in British Guiana}

LEAF scald disease, a bacteriological disease of extreme virulence which causes the sugar cane to wither and reduces its yield of sugar by fifty per cent or more, has recently been discovered on the sugar estates in British Guiana. It has previously been reported from sugar-growing areas in Mauritius, Queensland and Hawaii, where it was eventually brought under control by breeding resistant strains and enforcing plant-hygiene measures; but this is the first recorded case in the West Indian region. Mr. P. O. Wiehe, plant pathologist to the Government of Nyasaland, is to be seconded to British Guiana for six months to carry out research on the disease. The cost of Mr. Wiehe's visit is being shared equally between the British Guiana Government, the sugar industry in British Guiana and a grant made under a Colonial Development and Welfare Research Scheme.

\section{Echo-Sounding for Fish}

The Lowestoft Laboratory has issued a second report on the application of echo-sounding to fishfinding-especially in the pelagic fisheries - which bears the title "Echo-Sounding and the Pelagic Fisheries" (Ministry of Agriculture and Fisheries. Fishery Investigations, Series 2,17, No. 4 ; pp. 25 ; London: H.M. Stationery Office; 3s.). The efficacy of the modern echo-sounder for this purpose can now be considered proved; but improvements are possible and even now are on the way. Not only can fish shoals now be located with accuracy and ease in the wheelhouse, but also, perhaps even more important, is the fact that the echo-traces produced by certain kinds of fish-for example, herrings, pilchards, mackerel, sprats and certain gadoids-are shown to have recognizable characteristics that identify the species producing them. The fishing industry will be much indebted to Dr. W. C. Hodgson, the author of the report, and his colleagues for their pioneer work in this field.

\section{Bibliography of Scientific Publications of South Asia}

THE second number of the "Bibliography of Scientific Publications of South Asia (India, Burma, Ceylon)", covering July-December 1949 (Pp. 88. 